\title{
Bioeconomy and Circular Economy in the European Food Retail Sector
}

\author{
By Laura-Gabriela Istudor ${ }^{1}$, Marta-Christina Suciu ${ }^{1}$
}

\begin{abstract}
The paper highlights the importance of analysing corporations' activities and their policies addressing non-financial indicators, in line with the current global concerns regarding sustainability and bioeconomy. It aims at contributing to a better understanding of the concepts of circular economy and bioeconomy, while analysing corporations' behaviours regarding these topics. As Corporate Social Responsibility (CSR) standards have become frameworks for illustrating socially and environmentally responsible behaviours, the number of companies that adopt such standards for the elaboration of sustainability reports has increased. Since the publication of sustainability reports became mandatory as of 2018 , we consider that their documentation is in an incipient phase. This paper uses an empirical content-based analysis of sustainability reports released by corporations in the food retail sector inside the European Union. The selected retailers report non-financial performance following the guidelines of international social responsibility codes elaborated by the non-profit organization Global Reporting Initiative (GRI). The results of the analysis show different levels of involvement in sustainable practices across the corporations considered. Furthermore, the paper provides the main challenges regarding the implementation of sustainable methods of doing business, as well as the main impacts of adopting CSR standards for the supply chain.
\end{abstract}

Keywords: Bioeconomy, circular economy, sustainability, CSR, corporations

\section{Introduction}

The past years have brought to public attention the topic of sustainable development as a consequence of a decrease in resources, alarming pollution levels and global warming. There is an increasing need to design new efficient and effective ways to produce through sustainable methods, in order to ensure resources for future generations. Corporations around the world channel their efforts towards changing their ways of doing business by adopting CSR (Corporate Social Responsibility) codes, which promote non-polluting technologies and create new workplaces that make use of renewable energy sources.

The world's largest companies began to introduce into their business models measures that promote CSR, a decision that induces a positive image towards customers, as well as towards their own employees. In the context of creative economy, a concept that was first coined by John Howkins (2001), innovation based on exploring human creativity within different sectors of the economy, symbolically called creative industries, allows the development of new methods and techniques that can facilitate the long-run sustainable and inclusive development of the economy, while also protecting the environment. Companies performing activities in the bioeconomy sphere are preoccupied to offer 
social, economic and environmental wealth through the production and conversion of renewable biological resources.

Bioeconomy is among the European Union concerns within the 2020 Strategy objective of achieving smart, sustainable and inclusive development. In this regard, the Bioeconomy Strategy was launched in the public space by the European Commission in 2012. The main purposes of this strategy involve the development of new technologies for bioeconomy, expanding the bioeconomy sectors and achieving good co-operation between stakeholders and policymakers (European Commission, 2018). In order to support the sustainable development in Europe, as of 2018, the European Union legislation requires companies to include non-financial statements in the annual reports they issue, where the ways they tackle social and environmental challenges should be specified (European Commission, 2018). This directive is helpful for all entities involved, as it provides insight into the non-financial performance of corporations and drive them towards adopting responsible behaviours for their businesses.

Although there have been companies that published sustainability reports before 2018, the novelty of the European Union directive did not allow an extensive analysis of the available sustainability reports. On the other hand, corporations choose to report nonfinancial information through several available international standards, therefore exhibiting different forms. This paper selects food retailers from the European Union that use the GRI standards for issuing sustainability reports. It analyses the extent to which the sustainability reports published in 2018 include the GRI standards addressing environmental topics and activities specific to bioeconomy and circular economy. The paper is structured in four sections: a review of the scientific literature regarding CSR and the international standards for CSR reporting (section 1); the research methodology (section 2); the results of the analysis of the sustainability reports available on the web pages of the selected retailers (section 3); conclusions, followed by a highlight of the main theoretical and managerial implications (section 4).

\section{Review of the Scientific Literature}

Along the years, it has become of crucial importance for corporations to release non-financial information about their activities. In order to maintain the health of the planet, corporations are expected to include sustainable practices into their business models, as a 2017 report showed that 100 of the largest companies of the world have been responsible for a percentage of $71 \%$ of greenhouse gas emissions (CDP, 2017). The process of adopting sustainable actions in such companies turned out to be slow, a reason for authors to consider that careful guidance is required towards responsible actions (Baumgartner \& Rauter, 2017). Research in the field confirms that the transition from a linear economy to a circular economy leads to an increase in productivity (Vuţă et al., 2018), although this demands consistent financial efforts. On the other hand, consumers choose to purchase products from brands that strive for the adoption of sustainable behaviours. They search for information regarding production and packaging methods in order to ensure the lowest environmental impact following the consumption of a specific product (Dabija \& Bejan, 2017).

The concept of bioeconomy has been coined by a renowned Romanian origin 
economist, Nicholas Georgescu-Roegen (Iancu, 2006). According to D'Amato et al. (2017), bioeconomy and the circular economy involve "mobilizing resources and increasing their productivity through recycling and through adjusting the production processes (circular economy) and adapting the use of renewable resources (bioeconomy)". These authors analysed the presence of the two concepts of bioeconomy and circular economy in the sustainability reports of a sample of 123 companies from several industries. They highlight that while circular economy gathers economic, environmental and social objectives, bioeconomy focuses more on resources, biosecurity and rural policies (D'Amato et al., 2019). The circular economy approach involves keeping resources in the economy for a longer period, generating economic growth while minimizing the consumption of finite natural resources such as fossil fuels (Ishii, 2018).

In the context of creative economy and knowledge-based society, creativity and innovation can be highly valued in any sector of the economy, leading to an increase in productivity (Suciu, 2008). Therefore, companies from different sectors of the economy can make use of the knowledge generated by one another in order to develop new, smart, sustainable and inclusive ways of doing business. Richard Florida (2014), an author well recognised for the introduction of the concept of creative class, states that the development of the modern world is driven by the talented and gifted people, who contribute to the transformation of the way society works. The big cities of the world are expected to become creative, innovative and smart cities, driven by the use at a large scale of ITC (information technologies \& communications). It is also expected from the creative, innovative and smart cities and communities to conceive sustainable methods of development, that will also ensure sufficient natural resources for future generations.

The EU Directive 2014/95/EU that concerns the disclosure of non-financial information was made public in 2014, stating that organizations must issue reports on non-financial information as of 2018, covering the activity of 2017 . The directive applies to large companies of 500 employees or more (European Commission, 2018). Sustainable approaches in the business model of a corporation can prove to be a difficult and costly process. However, investments in this area can bring considerable profits in the long run, as well as customer awareness and appreciation. A study conducted by Unilever on 20000 adults shows that $33 \%$ of consumers choose to buy products from sustainable brands that are perceived as doing good socially or environmentally (Unilever, 2017).

The European Commission advises companies to report on their non-financial performance relying on international standards. These standards, such as the United Nations Global Compact or ISO 26000, offer more flexibility on the way the information is disclosed (European Commission, 2018). Corporate Social Responsibility (CSR) has been defined in the ISO 26000 standard as "the responsibility of an organization for the impacts of its activities on society and the environment through transparent and ethical behaviour" (International Organization for Standardization, 2010, p.3). Although the number of international CSR standards rises to hundreds, GRI remains the predominant one whose guidelines are used for drafting sustainability reports. According to the GRI website, $92 \%$ out of the largest 250 corporations of the world issue sustainability reports, while $74 \%$ of them make use of the GRI standards for their issue. Among these corporations, however, there is a relatively small number of 
retailers. There are currently 35 countries which use GRI in their sustainability policies and turn toward the non-profit organization for guidance, recognizing its position as the most used standard when it comes to sustainability reports. GRI addresses four categories of standards: universal, economic, environmental and social standards (GRI, 2018).

\section{Main Research Methodology}

The research methodology we used to elaborate this paper mainly consisted of analysing the sustainability reports of six of the largest grocery retail corporations in the European Union, ranked according to the revenue declared for 2017. Lidl was one of the retailers included in this ranking, but it could not be included in the analysis as the sustainability report for 2017 could not be found on the web pages of Lidl/Schwarz Group. In order to facilitate the analysis of the reports, they have been chosen from the list of retailers belonging to the European Union (excluding the United Kingdom). Therefore, we opted for the following retailers in the food sector which report nonfinancial data with the guidance of the GRI standards:

- Auchan Holding

- Abold Delhaize

- Carrefour Groupe

- Dia

- Migros Group

- REWE Group.

The reason for choosing food retail companies was their activity relevance for the concepts of bioeconomy and circular economy. At the same time, we took into consideration the power they inflict on the supply chain, being able to impact the production methods of the food sold in supermarkets. The sustainability reports are embedded in the last available annual reports of the companies analysed. They have been revised in order to identify the implemented strategies with respect to bioeconomy related activities and to the concept of circular economy. We also searched for to the measures taken by the companies towards a more sustainable way of conducting business and drew conclusions regarding their progress. Challenges encountered in implementing such strategies into the business models and the potential effects of adopting CSR codes on the supply chain have also been analysed. The latest reports available have been issued in 2018, containing information for the year 2017. In the analysed sustainability reports, we followed the presence of the eight GRI standards that address environmental topics, included in the so called 300 series of the GRI standards (presented in table 1). The analysis of the sustainability reports was carried out manually and it has been done searching for the numerical standard codes and by means of keywords related to the name of each standard. 
Table no. 1: The main GRI Environmental Standards

\begin{tabular}{|l|l|l|}
\hline $\begin{array}{l}\text { Environmental } \\
\text { standard }\end{array}$ & Topic & Background \\
\hline GRI 301 & Materials (2016) & Packaging materials, recycling, reusing materials \\
\hline GRI 302 & Energy (2016) & Energy consumptions and ways to reduce \\
\hline GRI 303 & $\begin{array}{l}\text { Water and effluents } \\
(2018)\end{array}$ & Water use and impact on water sources \\
\hline GRI 304 & Biodiversity (2016) & $\begin{array}{l}\text { Protecting biological diversity and natural } \\
\text { ecosystems }\end{array}$ \\
\hline GRI 305 & Emissions (2016) & $\begin{array}{l}\text { Greenhouse gas (GHG), ozone-depleting } \\
\text { substances (ODS), nitrogen oxides (NOX) and } \\
\text { sulphur oxides (SOX), and other air emissions }\end{array}$ \\
\hline GRI 306 & $\begin{array}{l}\text { Effluents and waste } \\
\text { (2016) }\end{array}$ & $\begin{array}{l}\text { Water discharges, disposal of waste, spills of } \\
\text { chemicals, oils, fuels, and other substances }\end{array}$ \\
\hline GRI 308 & $\begin{array}{l}\text { Compliance with environmental laws and/or } \\
\text { compliance (2016) } \\
\text { Eupplier } \\
\text { Environmental } \\
\text { Assessment (2016) }\end{array}$ & $\begin{array}{l}\text { Preventing and combating negative environmental } \\
\text { impacts in the supply chain }\end{array}$ \\
\hline
\end{tabular}

Source: authors' own synthetic presentation based on information from the official GRI website, www.globalreporting.org

We followed these steps to facilitate the identification of the extent to which the actions specific to the bioeconomy and the circular economy are found in the sustainability actions adopted by the companies under review.

\section{Main Results and Discussions}

There is a wide array of sustainable activities that corporations include into their business models and perform as part of their CSR strategies. For the relevance of the topic presented in this paper, we chose to focus on the ones related to the environment, and more specific to bioeconomy and circular economy. We therefore analysed the sustainability reports searching for the 300 series being used for the reporting of the material impact organizations have on the environment. The food retail corporations have an important impact on economic, social and environmental aspects in the countries where they operate. Due to the structure of their supply chain, they can directly impact the quality of the products farmers provide, while they also have an impact in food waste. Supermarket chains can support the production of organic food by increasing the demand towards their suppliers. They can support the production of food obtained through sustainable methods by only buying products from suppliers that provide such products.

CSR activities still remain voluntary and the EU Directive 34/2013 (modified by 95/2014) only requests that large companies include non-financial information in their annual reports, without specifying the means to get there. The topics addressed by the reviewed food retail corporations in their sustainability reports regarding the environmental factor 
are presented in table 2 , in accordance with the GRI-based hierarchy of standards:

Table no. 2: Presence of environmental GRI standards in the sustainability reports of the analysed retailers

\begin{tabular}{|l|c|c|c|c|c|c|}
\hline \multirow{2}{*}{ GRI Standard } & \multicolumn{5}{|c|}{ Presence of the GRI standard/retailer } \\
\cline { 2 - 8 } & $\begin{array}{c}\text { Auchan } \\
\text { Holding }\end{array}$ & $\begin{array}{c}\text { Ahold } \\
\text { Delhaize }\end{array}$ & $\begin{array}{c}\text { Carrefour } \\
\text { Groupe }\end{array}$ & Dia & $\begin{array}{c}\text { Migros } \\
\text { Group }\end{array}$ & $\begin{array}{c}\text { REWE } \\
\text { Group }\end{array}$ \\
\hline 301 Materials & yes & yes & yes & yes & yes & yes \\
\hline 302 Energy & yes & yes & no & yes & yes & yes \\
\hline 303 Water and effluents & no & no & no & no & no & yes \\
\hline 304 Biodiversity & yes & yes & yes & no & no & yes \\
\hline 305 Emissions & yes & yes & yes & yes & yes & yes \\
\hline 306 Effluents and waste & yes & yes & yes & yes & yes & yes \\
\hline 307 Environmental compliance & no & no & no & yes & no & no \\
\hline $\begin{array}{l}\text { 308 Supplier Environmental } \\
\text { Assessment }\end{array}$ & yes & yes & yes & no & no & yes \\
\hline
\end{tabular}

Source: authors' conception based on the information in the analysed sustainability reports

The results presented in table 2 show the fact that between the eight GRI 300 series, chapters 303 (Water and effluents) and 307 (Environmental compliance) are the least approached, while almost all the analysed retailers chose to publish information regarding the rest of the chapters. Regarding the 301 Materials standard, the most present activity in recovering waste is the recycling of plastic, paper, batteries etc. In Auchan Holding (2018), plastic is recycled and reused as plastic bags sold at the counters of the supermarkets. In REWE Group (2018), where possible, plastic packaging is replaced with stickers made of renewable materials such as recycled or certified paper. The 302 Energy standard is tackled by using renewable sources of energy such as solar panels in the case of Auchan Holding (2018), the use of a wood-fired heating plant in the case of Migros (2018) or transforming inedible food waste into electricity supply in the case of Ahold Delhaize (2018). As mentioned in the sustainability report of Auchan Holding (2018), water consumption proves to be difficult to track due to large number of suppliers and long periods between billing, while other sustainability reports chose to not approach the 303 Water and effluents standard in their 2017 reports. The German retailer REWE is the only one that mentions in the report that it installed equipment in supermarkets, promoting the reduction of water consumption. The 304 Biodiversity standard is addressed by means of principles of environmental protection to producers. For the food retailers, these actions involve selling products such as certified bananas or other certified products obtained by minimizing the environmental impact under the strict supervision of international associations. The 305 Emissions standard is present in all the sustainability reports reviewed, through actions specific to the retail industry in using natural refrigerants, renewing the lorries fleet and introducing natural gas powered lorries. The 306 Effluents and waste standard appears in various forms of disposing of waste and reducing the percentage of waste of the analysed retailers. In this matter, the circular economy concept is highlighted in the sustainability reports, as waste is turned into resources through various methods and reused in the productive economy circle. Other activities besides recycling, involve methanation, composting, vermicomposting and recovering waste for energy production. The production of biogas saves energy and 
leads to the reduction of costs in processing organic waste. Such bioeconomy related activities are rarely implemented within the analysed food retailers, except Auchan Holding, which distinguishes itself from the other retailers by the increased number of these actions. GRI standard 307 Environmental compliance is not directly addressed, however the analysed sustainability reports highlight their compliance with international regulations and efforts towards minimising their environmental impact. The only retailer analysed that mentioned standard 307 in the report is Dia (2018), which addressed the topic by briefly stating that part of the group's environmental policy is to "comply with existing regulations". The German retailer REWE mentions that it does not intend to collect data on this standard because the effort made to collect them would not be proportionate to the benefits expected to be obtained. As regards the 308 Supplier Environmental Assessment, adopting social responsibility codes has certain effects on the supply chain of food retail corporations. Therefore, all the environmentally friendly measures adopted also involve the regulation of suppliers' activities. Suppliers must comply with quality criteria and are controlled in order to verify conformity with environmental standards regarding pollution (of the water, air, soil, etc.) and electricity consumption. They must also follow guidelines on a wide range of products such as sustainable palm oil, sustainable cocoa, sustainable fish and others in order to protect biodiversity. Non-compliance with the imposed regulations leads to penalties or supplier contracts being rescinded. The share of standards included in the GRI 300 series in the retailers' sustainability reports can be seen in Figure 1:

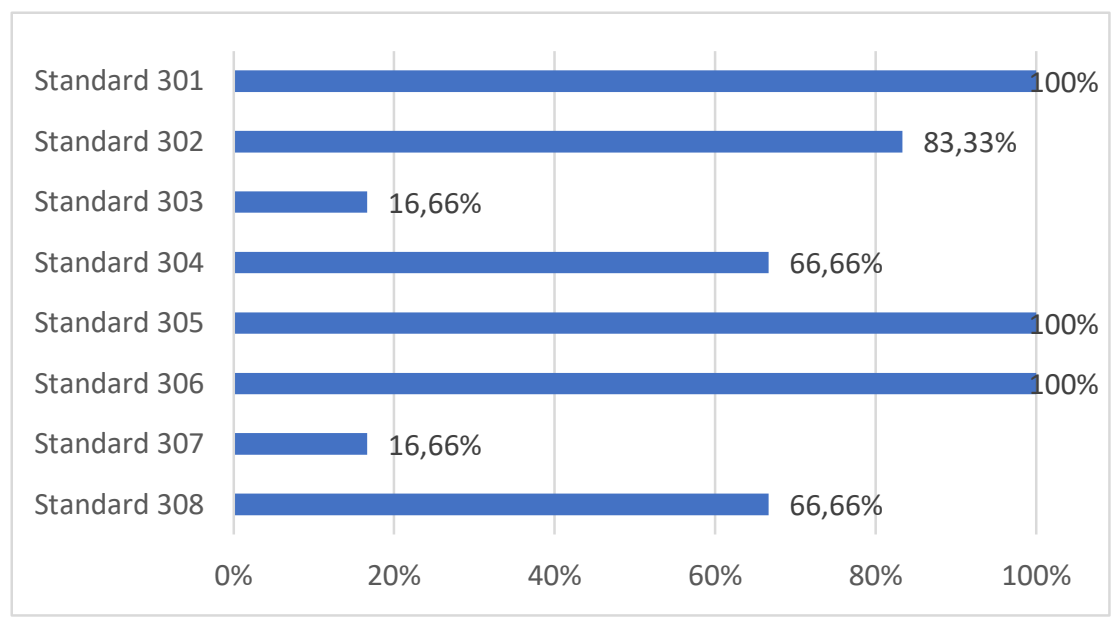

Figure 1: Percentage of standards 300 in the sustainability reports analysed

Source: authors' conception based on the information in the analysed sustainability reports

Although the sustainability reports of the analysed retailers highlight the improvements of the last years in terms of social responsibility, there are a few mentions of the impediments they found in implementing, measuring or reporting of certain activities. Among the challenges encountered by the analysed corporations when it comes to incorporating into their business models environmental CSR activities, the following 
have been stated:

- The recovery rates and sorting waste procedures vary in each country depending on regulations and the lack of official recovery circuits.

- There is a low profitability in sorting biowaste, due to difficulties in establishing a system for recovering it.

- The inexistence of methanation procedures in place in many countries of the European Union.

- The lack of space for installing and sorting composters for the majority of the retailers.

- Changes in waste management activities bring the need for investment in staff training on the topic.

- Water consumption results very difficult to track and report due to long periods between billing and large number of suppliers, due to retailer presence at international level.

- Information on reuse or disposal of waste is not always available, as recycling activities are performed by local town councils.

As circular economy is a current concern of the European Commission, companies are highlighting the measures taken in this respect, in order to legitimize themselves. Circular economy is mentioned in all the sustainability reports analysed, together with the steps resources are subjected to until becoming again a resource. Table 3 depicts the circular economy specific actions adopted by the analysed European food retailers:

\section{Table no. 3: The main actions specific to the Circular Economy}

\begin{tabular}{|c|c|}
\hline Retailer & Type of action \\
\hline $\begin{array}{l}\text { Auchan } \\
\text { Holding }\end{array}$ & $\begin{array}{l}\text { - The use of a methanisation reactor to produce biogas from food waste } \\
\text { - Fruit and vegetable waste is vermicomposted, creating a natural soil-enriching } \\
\text { agent used to grow organic products } \\
\text { - Plastic collected and sorted in stores is recycled and turned into plastic bags sold } \\
\text { at the tills of Auchan supermarkets } \\
\text { - The development of urban farms with the use of bio waste as fertilizer }\end{array}$ \\
\hline $\begin{array}{l}\text { Abold } \\
\text { Delhaize }\end{array}$ & $\begin{array}{l}\text { - Two of the group's brands, Albert Heijn and Delhaize Belgium, recycle } 100 \% \text { of } \\
\text { food waste } \\
\text { - Two of the group's brands, Giant Carlisle and Hannaford, are responsible for a } \\
16 \% \text { increase in food waste recycling for biogas generation compared to } 2016\end{array}$ \\
\hline $\begin{array}{l}\text { Carrefour } \\
\text { Groupe }\end{array}$ & - The retailer recovered $70 \%$ of waste in 2017 through recycling \\
\hline Dia & $\begin{array}{l}\text { - Involvement in a project that recycles Expanded Polystyrene (EPS) waste and } \\
\text { converts it into packaging }\end{array}$ \\
\hline $\begin{array}{l}\text { Migros } \\
\text { Group }\end{array}$ & $\begin{array}{l}\text { - } 35 \% \text { of PET bottles for the Ice Tea range consist of recycled PET } \\
\text { - The coffee powder in coffee capsules is added to animal feed or compost, while } \\
\text { the plastic capsules are recycled }\end{array}$ \\
\hline $\begin{array}{l}\text { REWE } \\
\text { Group }\end{array}$ & - The packaging of body care products is being switched to recycled materials \\
\hline
\end{tabular}

Source: authors' conception based on the information in the analysed sustainability reports

Table 3 shows that the degree of involvement in actions specific to the circular economy 
differs from one retailer to another according to their number and complexity. While the circular economy is a concept found in all the analysed sustainability reports, the concept of bioeconomy is not mentioned as such in any of the reports, although there are specific activities implemented, such as biogas production. These efforts are being made by corporations to highlight the processes implemented towards alignment with both the European Commission's requirements and the international concerns on sustainable development. Similar studies have revealed that the circular economy is a concept that is found in most sustainability reports of companies belonging to various sectors of the economy. At the same time, bioeconomy appears in a small percentage, with the exception of the energy sector, followed by food and beverages (D'Amato et al., 2019). In the food retail sector, other studies show that some of the retailers analysed in this paper (including Auchan, Carrefour, REWE, Abold Delhaize) provide information referring to no more than 13 standards, from the total of 33 standards gathered under the umbrella of GRI (Dabija \& Bejan, 2018).

\section{Conclusions}

Since sustainability has become one of the main topics concerning the world population, international policies and standards have started to impact the way companies design their business models and report on environmentally friendly practices. We consider that analysing the non-financial information of corporations is a valuable step towards evaluating their contribution to shifting the global economy to more sustainable production methods. As the EU Directive 2014/95/EU requires companies with over 500 employees to publish non-financial information as of 2018, the annual reports of European corporations for 2017 contain information and statistics regarding their efforts towards more sustainable methods of doing business. As the European Commission advises, there are several international CSR standards that can guide companies in the implementation of sustainable actions as well as in drafting their annual sustainability reports. Among these, GRI is the predominant one, with $74 \%$ of the largest companies publishing sustainability reports using it as a guideline (GRI, 2018). Following the analysis of the sustainability reports of six European food retailers, published in 2018 and covering data from 2017, with the purpose of finding the presence of the GRI 300 series standards and information related to bioeconomy and circular economy, the conclusion is that the selected corporations strive to exhibit the efforts they channel into limiting waste, recycling and reducing emissions. While offering detailed information about the positive results obtained, the analysed retailers offer less to none information regarding certain activities impacting the environment, such as water consumption. Circular economy is a present concept in all the sustainability reports analysed, in the attempt of the retailers to show the adoption of principles promoted by the European Commission and to popularize such practices among consumers. The most notable practices reported included: transforming waste into biogas; recycling plastic waste and transforming it into plastic bags to sell at the counters; coordinating between suppliers in order to reuse products not fit for selling as resource for the creation of new products. Bioeconomy related activities, while not mentioned as a concept, are present in the sustainability reports of the reviewed retailers in the form of 
use of renewable biological sources (electricity provided through the means of solar panels; the use of methanisation reactors to produce biogas from food waste; or the use of certified paper stickers instead of plastic wrapping). Adopting sustainable measures in line with existing international standards and publishing them are actions that can bring a competitive advantage in a society where consumers are concerned about protecting the environment. This type of behaviour is a benefit for the stakeholders of any corporation (Unilever, 2017). We believe that this work can contribute to the development of knowledge regarding sustainable Corporate Social Responsibility in terms of the relationship between companies, the environment and society. The analysis of corporate sustainability reports can also serve as an example of good practice for other companies seeking to implement sustainable practices. Furthermore, we consider that this analysis of sustainability reports stands as a starting point for future research on the measures taken by corporations to decrease their environmental impact and contribute towards shifting the economy to more sustainable ways of production by relying on renewable resources.

\section{References}

Auchan Holding, 2018. Annual report 2017. [online] Available at: <https://www.auchanretail.com/uploads/files/modules/columns/1524671315 5ae0a35395e28.pdf> [Accessed 15 March 2019]

Baumgartner, J. and Rauter, R., 2017. Strategic perspectives of corporate sustainability management to develop a sustainable organization. Journal of Cleaner Production, 140(1), pp. 81-92. https://doi.org/10.1016/j.jclepro.2016.04.146.

Carrefour Groupe, 2018. Annual report 2017. [online] Available at: $<$ http://www.carrefour.com/sites/default/files/carrefour - 2017 annual report.pdf $>$ [Accessed 15 March 2019]

CDP, 2017. CDP Carbon Majors Report 2017. Available at: <https://b8f65cb373b1b7b15febc70d8ead6ced550b4d987d7c03fcdd1d.ssl.cf3.rackcdn.com/cms/reports/documents/000/002/32

7/original/Carbon-Majors-Report-2017.pdf> [Accessed 15 March 2019]

Dabija, D.C. and Bejan, B.M., 2017. Behavioral Antecedents for Enhancing Green Customer Loyalty in Retail. In: Pamfilie, R., Dinu, V., Tăchiciu, L., Pleșea, D., Vasiliu, C., (Eds.), BASIQ International Conference: New Trends in Sustainable Business and Consumption. Vol. 1. Editura ASE, Bucharest, 2017, pp. 183-191.

Dabija, D.C. and Bejan, B.M., 2018. Sustainability reporting of grocery retailers on an emerging market. In: BASIQ International Conference: New Trends in Sustainable Business and Consumption. Heidelberg, Germany, 31 May-3 June 2018. Editura ASE, Bucharest, pp. 611-619.

D’Amato, D., Droste, N., Allen, B., Kettunen, M., Lahtinen, K., Korhonen, J., Leskinen, P., Matthies, B. D. and Toppinen, A., 2017. Green, circular, bio economy: A comparative analysis of sustainability avenues. Journal of Cleaner Production, 168(1), pp. 716-734. https://doi.org/10.1016/j.jclepro.2017.09.053

D'Amato, Korhonen, and Toppinen, A., 2019. Circular, Green, and Bio Economy: How Do Companies in Land-Use Intensive Sectors Align with Sustainability Concepts?. Ecological Economics, 158, pp.116133. https://doi.org/10.1016/i.ecolecon.2018.12.026.

Dia, 2018. Annual report 2017. [online] Available at: $<$ https://memoriaanual2017.diacorporate.com/recursos/doc/memoria2017/2018/03/16/busine ss-and-sustainability-report.pdf $>$ [Accessed 15 March 2019]

European Commission, 2018. The Bioeconomy Strategy. Available at:

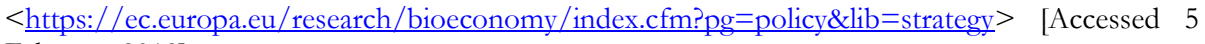
February 2019] 
European Commission, 2018. Non-financial reporting. Available at: <https://ec.europa.eu/info/business-economy-euro/company-reporting-andauditing/company-reporting/non-financial-reporting en > [Accessed 5 February 2019]

Florida, R., 2014. The Creative Class and Economic Development. Economic Development Quarterly., 28, pp. 196-205. https://doi.org/10.1177/0891242414541693.

GRI, 2018. GRI and Sustainability Reporting. Available at: <https://www.globalreporting.org/information /sustainability-reporting/pages/gri-standards.aspx > [Accessed 12 February 2019]

Howkins, J., 2001. The Creative Economy: How People Make Money From Ideas. United Kingdom: Penguin UK.

Iancu, A., 2006. Opera lui Nicholas Georgescu-Roegen, OEconomica issue 01. Available at: $<$ https://econpapers.repec.org/article/oeneconom/y 3a2006 3ai 3a01 3aid 3a73.htm>

[Accesed 12 February 2019]

International Organization for Standardization, 2010. ISO 26000 - Guidance on Social Responsibility. [pdf] International Organization for Standardization. Available at: <https://iso26000.info/wpcontent/uploads/2017/06/ISO-26000 2010 E OBPpages.pdf $>$ [Accessed 12 February 2019]

Ishii, N., 2018. The Future of the Global Commons: A Call for Collective Action. Encyclopedia of the Antbropocene, 3, pp. 471-476. https://doi.org/10.1016/B978-0-12-809665-9.09865-7.

Migros Group, 2018. Progress Report 2017. Available at: $<\underline{\text { https://report.migros.ch/2017/en/progress-report- }}$ 2017/environment/energy-climate/> [Accessed 12 February 2019]

REWE Group, 2018. REWE Group Sustainability Report 2017. Available at: < https://rewe-groupnachhaltigkeitsbericht.de/2017/en/gri-report/green-products/gri-308-environmental-standardsin-the-supply-chain/index > [Accessed 15 March 2019]

Suciu, M. C., 2008. The Creative Economy. Lex et Scientia, 15(1), pp. 145-154. Available at: ResearchGate website < https://www.researchgate.net/publication/42437328 THE CREATIVE ECONOMY> [Accessed 5 February 2019]

Unilever, 2017. Report shows a third of consumers prefer sustainable brands. Available at: Unilever website $<$ https://www.unilever.com/news/press-releases/2017/report-shows-a-third-of-consumersprefer-sustainable-brands.html> [Accessed 10 March 2019]

Vuță, M., Vuță. M., Enciu, A. and Cioacă, S.I., 2018. Assessment of the Circular Economy's Impact in the EU Economic Growth. Amfiteatru Economic, 20(48), pp. 248-261. 